\title{
Determination on the Success of Cataract Surgeries by Using Sight Restoration Rate (SRR)
}

\author{
Angelo Doniho ${ }^{1 *}$, Angela Shinta Dewi Amita ${ }^{1}$, Cisca Kuswidyati ${ }^{1}$, Devina Permatasari ${ }^{1}$, \\ Andrew Adiguna Halim ${ }^{2}$ \\ ${ }^{1}$ Departemen Mata, FKIK, UNIKA Atma Jaya, Jl. Pluit Selatan Raya No.19, Penjaringan, Jakar- \\ ta Utara, DKI Jakarta 14440, Indonesia. \\ ${ }^{2}$ Department of Health Science, The University of Canterbury, 20 Kirkwood Ave, Upper Riccar- \\ ton, Christchurch 8041, New Zealand. \\ *oedama.olegna.250689@gmail.com
}

Submisi: 27 April 2018; Penerimaan: 05 April 2019

Keywords:

cataract surgery; eye health services; productivity
Abstract The prevalence of blindness in Nusa Tenggara Timur (NTT) reaches $1.0 \%$ and the ratio of blindness to ophthalmologist reaches 1:8000. This data means NTT is a place which has vision issues. Blindness is caused by cataract. Untreated cataracts can reduce the productivity of patients and his/her caretaker for quite a long time. Cataract surgery will not only cure the patient's blindness, but it will also improve the local economy if it is sustainable and on time. Lack of human resources, funds, and medical equipment are the major problems for performing cataract surgery in this area. The cataract surgery is performed at Elisabeth Lela Hospital. Visual acuity is performed before the surgery and 21-35 days after the surgery. The last step is calculating the Sight Restoration Rate (SRR) of all patients. Cataract surgery was conducted to 92 eyes. the SRR of all patients is $46.7 \%$. There are four eyes $(4.34 \%)$ with post-operative visual acuity $<3 / 60$.

\section{INTRODUCTION}

The eyes are the sensory organs which have an important role in human's ability to see.

According to WHO data in October 2018, there were 217 million of people around the world with severe visual impairment. Furthermore, 36 million people were blind. Blindness causes difficulty in providing a stable livelihood for the family, participating in social activities, and doing daily activities. Moreover, blind people will become a burden for their family economically and socially due to the stigma towards people with disability. 
All of that will affect the country's economic conditions later (World Health Organization, 2018).

WHO campaigned, Vision 2020 program, is to overcome blindness and disabilities related to vision around the world. In Indonesia, Vision 2020 was accepted by president Megawati Soekarnoputri in 2000. The aim of this program is to treat all vision visual impairments around the world which can be prevented or cured (World Health Organization, 2012). A cataract is one of the blindness which can be cured by replacing the cloudy lens with an artificial intraocular lens. Replacing the lens will not only restore the patient's visual acuity but will also restore their quality of life. Atma Jaya Community Opthalmology Program and Education (ACOPE) Atma Jaya conducted cataract surgeries in a place where it is the most needed. The researchers would like to analyze the impact of the cataract surgeries which was performed in Elisabeth Lela Hospital.

\section{PROBLEM}

$50 \%$ of blindness in the world is caused by cataract (Wang et al., 2016). In Indonesia, 500.000 cataract surgeries are needed every year. Perdami statistical report showed there were only about 150,000 to 180,000 cataract surgeries performed in a year. It means there are an additional 320,000-350,000 people who need cataract surgery but they are not able to get it every year (InfoDatin, 2013).

In 2013, the prevalence of blindness in Nusa Tenggara Timur (NTT) province was around $1.0 \%$. This number is $0.4 \%$ higher than the prevalence of national-level blindness. Moreover, NTT has the highest ratio of blindness to the available ophthalmologist, which is $8000: 1$. While the national number was 1:344 (Badan Penelitian dan Pengembangan 
Kesehatan, 2013), Sikka had 315.477 blind people in 2016 (Sikka, 2017). Since the prevalence of blindness in NTT was 1\%, the researchers assume that there are around 3,154 people who need cataract surgery.

\section{METHODS}

Medical records of patients who did Small Incision Cataract Surgery (SICS) in March 2018 at Elisabeth Lela General Hospital, Sikka, NTT. Physical and keratometry examinations were performed using the same instruments before the surgery and 21-35 day after the surgery. In addition, best corrected visual acuity (BCVA) was conducted using the Snellen chart and a pinhole. All of the eye examinations were performed by the same operator. Pre- and post-BCVA were categorized into four categories according to WHO classification. The categories are 6/6-6/18, <6/18-6/60, <6/60-3/60, and $<3 / 60$-No Light Perception.

The frequency of each BCVA categories is taken into accounts. After that we consider frequency and proportion of co-morbidities of the patients. Sight Restoration Rate is calculated using the following formula (Limburg et al., 1996):

$$
\mathrm{SRR}=\frac{\mathrm{P}(\text { pre })-\mathrm{P}(\text { post }) \times 100}{\text { total catops } / \text { year }}
$$

$\mathrm{SRR}=$ Sight Restoration Rate

$\mathrm{P}($ pre $)=$ number of patients with $\mathrm{BCVA}<3 / 60$ on either eye before the surgery

$\mathrm{P}($ post $)=$ number of patients with $\mathrm{BCVA}>3 / 60$ on the operated eye

Total catops/year $=$ number of the performed cataract surgery 
In addition, this study received the ethical clearance from the Ethical Committee of Catholic University of Atma Jaya on February 28, 2018 (No: 12/02/KEP-FKUAJ/2018).

\section{RESULTS}

The result of the research is referred to surgeries were performed on 92 eyes. From 92 eyes, 83 were considered blind while the other 9 were severely broken. Four of the visual impairments could not be cured due to co-morbidities. 17 eyes have secondary co-morbidities (18.48\%). Secondary comorbidities; are retinopathy (12 people) glaucoma (4 people), and optic neuropathy (1 people) will influence the outcome of the cataract surgery. The SRR of the surgery in this research is $46.75 \%$. SRR is an indicator to determine the impact of conducting cataract surgeries on people's productivity. In measuring SRR, the best visual acuity of either eye in a patient before the surgery is used. If the best visual acuity of either eye is already more than $3 / 60$, then the cataract surgery is not considered as having an effect on people's productivity. This is the key difference which differentiates SRR from other indicators which are used to determine the success of cataract surgery. Two patients were still blind even after the surgery, whom the surgery had no effect in restoring the patient's sight. After further investigation, the patient had retinitis pigmentosa and the other one has an optic neuropathy.

A study in the United States showed cataract surgery not only restores the patients' life quality but also has a very high return on investment (ROI) up to $4567 \% 13$ years after the surgery (Wang et al., 2016). Another study stated cataract surgery is one of the most effective health interventions which will reduce the cost of rehabilitating the patient with a disability with an estimated reduction of 20-40\$/year/people (Murthy et al., 2008). 
It happens because blindness has a huge correlation with economic productivity of its victim and the caretakers for a very long time if it is not cured (Wang et al., 2016).

The cataract surgeries at Elisabeth Lela hospital on NTT were performed by the ophthalmology team from Atma Jaya. NTT is chosen as the place to do the community service because the number of blindness in NTT is the second highest in Indonesia and it has the lowest ratio of ophthalmologists to blindness in Indonesia (Badan Penelitian dan Pengembangan Kesehatan, 2013). One of the indicators of the success of the cataract surgeries is the Sight Restoration Rate (SRR) (Murthy et al., 2008). SRR shows the percentage of patients whose sight restored after the surgery. The weakness of using SRR is this measure can be influenced by selectively removing patients whose sights failed to be restored. However, all patients who were operated during the study period are also included to minimize the bias.

Performing eyes surgery with BCVA more than 3/60 are not the goal of Vision 2020. The eyes surgery's main goal is not only to reduce the numbers of blindness but also to increase patients' life quality (Limburg et al., 1996). The SRR of the eyes surgery in this study is $46.70 \%$. This number is higher than other surgeries performed by Eye camps (39\%), Ludhiana (35\%), and Ludhiana'94 (28\%) (Limburg et al., 1996).

The result of surgeries performed by the researchers, however, is not yet optimal because the researchers also operate the patient's second eyes twice. Furthermore, due to unconfirmed secondary eye problems which would have only known after the researchers do the surgery to the patients. The better way to selectively choose those who would gain the most benefit from the surgery is needed. Hence, some patients who have a bad prognosis still need the surgery to prevent the later complications (e.g. hyper-mature cataract 
which can lead to capsular fibrosis, phacolytic-phacoanaphylactic reaction, or zonula dialysis). Developing countries have a high number of blindness because some residences are far from health facilities. Timely and more targeted screening is essential in resolving this problem (Khandekar et al., 2016; Mahalingam, 2005). Another important factor in handling this problem is to empower the communities to socialize the benefit of cataract surgery. A study showed $2 / 3$ of patients are convinced to have the surgery due to the encouragement from family or close relatives. (Mahalingam, 2005)

Another factor which can be used to determine the success of cataract surgery is the proportion of patients with the poor surgical outcome (i.e. BCVA $<3 / 60$ ) (Limburg et al., 1996). The proportion of BCVA $<3 / 60$ of the eyes surgery in this study is $4.34 \%$. This number is lower than the criteria from WHO for poor outcome, which is $5 \%$ (Malik et al., 2016). The main cause of poor outcome is uncorrected refraction problem, comorbidities, and surgical complications. The quality of cataract surgery can be improved by retraining the operator, improving the health system, facilities, and surgical equipment, and establishing a better monitoring system (Isawumi et al., 2009). Unfortunately, the lack of human resources is still the main problem in developing countries. There must be a balance between intervention costs and its results when conducting cataract surgery in resource-limited settings (Khandekar et al., 2015).

\section{CONCLUSION}

SRR of the surgery in this research is $46.75 \%$, while our poor surgical outcome is $4.34 \%$. High SRR means that alot of these patients can return to work, while poor surgical outcome means that the surgeries have very good standard. This will optimize "peoples right 
for sight" as was suggested with Vision 2020 motto.

Similar research in the same areas at a different time can be done to know whether the project can further increase their effectiveness in providing people with sight. Further research in different areas can also be done to see the place that needs help the most. Furthermore it can give a picture about the nation's problem in sight.

\section{REFERENCES}

Badan Penelitian dan Pengembangan Kesehatan. (2013). Riset Kesehatan Dasar (RISKESDAS) 2013. Laporan Nasional 2013. https://doi.org/1 Desember 2013

InfoDATIN. (2013). Situasi Gangguan Penglihatan dan Kebutaan.

Khandekar, R., May, W., \& Alasbali, T. (2015). Indicators for monitoring cataract surgery outcomes; evolution and importance. Nepalese Journal of Ophthalmology, 7(1),

\section{3. https://doi.org/10.3126/nepjoph.v7i1.13144}

Khandekar, R., Sudhan, A., Jain, B., Deshpande, M., Dole, K., Shah, M., \& Shah, S. (2016). Impact of cataract surgery in reducing visual impairment: A review. Middle East African Journal of Ophthalmology. https://doi.org/10.4103/09749233.148354

Limburg, H., Kumar, R., \& Bachani, D. (1996). Monitoring and evaluating cataract intervention in India. The British Journal of Ophthalmology, 80(11), 951-5. https:// doi.org/10.1136/bjo.80.11.951

Malik, A.R. et al. (2016). Cataract Surgery Visual Outcomes and Associated Risk Factors in Secondary Level Eye Care Centers of L V Prasad Eye Institute. British Journal of Ophthalmology, 20(1), 1-11. https://doi.org/10.5061/dryad.71hp4.Funding 
Murthy, G.V.S., et al. (2008). Current status of cataract blindness and Vision 2020: The right to sight initiative in India.

Isawumi, E. S., \& Adeoti, AO Adeoye, C. O. A. (2009). Evaluation of Cataract Surgery Outcome in Western Nigeria. Ghana Med J. Retrieved from https://www.ncbi. nlm.nih.gov/pmc/articles/PMC2956367/

Mahalingam, K. (2005). Evaluation of cataract surgical service delivery to the visually impaired. The Indian Journal of Social Work, 66(3), 280-309. Retrieved from http:// search.ebscohost.com/login.aspx?direct $=$ true $\& d b=$ swh $\& A N=77436 \&$ site $=e-$ host-live \&scope $=$ site

Sikka (2017). Kabupaten Sikka dalam Angka. Diakses dari https://sikkakab.bps.go.id/ publication/2017/08/11/daf1 f86981cd62e5eccec216/kabupaten-sikka-dalam-angka-2017.html

Wang, W., Yan, W., Fotis, K., Prasad, N. M., Lansingh, V. C., Taylor, H. R., ... He, M. (2016). Cataract surgical rate and socioeconomics: A global study. Investigative Ophthalmology and Visual Science, 57(14), 5872-5881. https://doi.org/10.1167/ iovs.16-19894

WHO. (2018). Blindness and Vision Impairment.

World Health Organization. (2012). WHO: Visual Impairment and Blindness. WHO. 96. 